\title{
A SERVANT OF GOD, THE CHURCH AND HOMELAND. ON THE TENTH DEATH ANNIVERSARY OF ARCHBISHOP MARIAN OLEŚ 1934-2005
}

On 24 May 2005 Archbishop Marian Oleś died suddenly in Warsaw at the age of 70 with 44 years of priesthood and 18 years of the Episcopal ministry in the service of the Holy Father and the Holy See. His mortal remains were buried in the Polish Necropolis-at Powązki Cemetery in Warsaw.

\section{$* * *$}

As a Pole by birth, he lived in his homeland only five years. He was born on 8 December 1934 on the feast of the Immaculate Conception of the Blessed Virgin Mary in Cendrowizna, in the parish of Miastkowo in the Diocese of Łomża. He was the son of Jan (aged 33) and Franciszka (aged 32) from Tyszków. His father was a forester of the state forests in Cendrowizna. On 20 December the same year, he was baptized in the parish church of Our Lady of the Rosary in Miastkowo by the then curate of the parish Rev. Franciszek Łuba. His godparents were: Stefan Klimaszewski and Irena Woźniak ${ }^{1}$.

On 11 February 1940, he was, along with his family, deported to Arkhangelsk. It was the moment when he, as a five-year child, began his life in exile. Returning

\footnotetext{
${ }^{1}$ The parish of Miastkowo was erected in 1451 by the Bishop of Płock Paweł Giżycki from the foundation of Boleslaw II of Masovia. The present parish church dedicated to Our Lady of the Rosary is historically the third parish church, consecrated on 27 October 2013 by the Bishop of Łomża Janusz Stępnowski. The first wooden church was dedicated to Assumption of the Blessed Virgin Mary, St. James the Apostle and 10.000 Martyrs; the second parish church dedicated to Saints Peter and Paul was consecrated in 1767. The Archive of the Parish of Miastkowo, The register of the baptized in the parish of Miastkowo no 156/1934; Konsekracja Kościoła pod wezwaniem Matki Boskiej Różańcowej w Miastkowie, Miastkowo, 27 October 2013, pp. 3-6.
} 
from the Soviet captivity, first he travelled through Persia (today's Iran), where his father $\operatorname{died}^{2}$, then through Pakistan to India, where he attended elementary school.

After the Second World War, his family settled in Melton Mowbray, in central England. There he graduated from high school. He had felt his vocation to the priesthood since he was a child, so in the fall of 1954 he came to the Pontifical Polish College in Rome ${ }^{3}$ and began his theological studies at the Gregorian University ${ }^{4}$. Upon its completion on 9 July 1961, he was ordained as priest by Archbishop Pericle Felici, the future cardinal, who announced to the world that John Paul II was chosen pope. Then Rev. Oleś continued his studies in law at the Lateran University, where he obtained a doctorate in canon law ${ }^{5}$.

In the same year he was admitted to the university of Vatican diplomacy - the Pontifical Ecclesiastical Academy ${ }^{6}$. Upon its completion in autumn 1966, Rev. Marian Oleś was appointed as employee of the Apostolic Nunciature in Ecuador.

\footnotetext{
${ }^{2}$ Iran was the first stage of the journey of the exiles from the Soviet Union to their homeland. However, for many - the last one. The years of homelessness, prisons and labour camps, exhausting work, diseases took a heavy toll. In the area of Persia died nearly 3.000 Polish refugees, including 650 military ones. None of them, however, died on the battlefield. They died as a result of diseases and poverty. Father of Archbishop Oleś died in Tam and was buried in the cemetery Dulab in Tehran, the largest Polish cemetery in Iran. The Archbishop, as an employee of the Nunciature in Tehran, did a lot to maintain the local Polish graves. On 21 April 2002, the Bishop of the Polish Army Rev. Sławoj-Leszek Głódź consecrated this cemetery. After years, the Archbishop followed the footsteps of the past, but from the opposite direction - from Tehran, Kazakhstan to Central Europe M. Rutkowska, Z ziemi perskiej do Polski, [in:] „Kresowe Stanice”, No 3/2002 (18) Year VI Warsaw September 2002, pp. 92-96.

${ }^{3}$ The Pontifical Polish College - a formation house in Rome, on the Aventine Hill (Piazza Remuria 2A) for the priests who were sent to the eternal city by Polish bishops to do specialist studies at church universities. The Polish College in Rome was founded on 1 September 1582 by Philip Neri. Due to economic reasons, after a few years it was closed. An attempt to resurrect it was taken by King Jan II Kazimierz Waza in 1653. The College resumed its activity in 1866 thanks to the efforts of Rev. Piotr Semenenko. It was run by Resurrectionists. After World War II, the Jesuits took over the college. Since 1959, the Polish Bishops' Conference has had it under its care.

${ }^{4}$ The Gregorianum - the Jesuit university in Rome, founded in 1551 by Ignatius Loyola. In recognition of Pope Gregory XIII's merits the university adopted the name of the Gregorian University or the Gregorianum. Additionally, national colleges were established for foreign students at the university. Dozens of saints and blessed, and 16 popes (until 1993) graduated from the Gregorian University. Also, the Poles studied there. E. Nowak, Gregorianum, [in:] Catholic Encyclopaedia, volume 6 Lublin 1993, columns 133-134.

${ }^{5}$ Webpage: http://www.kuria.lomza.pl/index.php?wiad=10, lecture of 2 February 2016.

${ }^{6}$ The Pontifical Ecclesiastical Academy (Italian Pontificia Accademia Ecclesiastica) - it is home to the formation of future employees of the Vatican diplomacy. It is not a university, as it does not award degrees. Its employees represent the Holy Father in the countries with which Vatican has diplomatic relations. The academy holds the following classes: specialized lectures in the field of diplomacy, foreign language courses and organizes studies in the 21 pontifical universities in Rome for future diplomatic staff. Today more and more countries want to have Vatican diplomatic posts. The diplomatic work of the Holy See differs significantly from all the institutions of this type. Its task is a mission of evangelization and widely understood communication with churches in other countries, and the Holy See has largely focused on spreading peace and struggling for human digni-
} 
In 1970 he became a secretary of the Nunciature in Indonesia. For three years he worked as an adviser of the Nunciature in Tehran. The next three years he spent at the diplomatic post in Lisbon. In 1977 he returned to the Roman Curia, where he worked for 10 years in the Congregation for Bishops ${ }^{7}$ as a head of the European section. In 1967, Pope Paul VI appointed Rev. Oleś as his own chaplain, and in 1983 Pope John Paul II granted him the title of an honorary prelate.

On 28 November 1987, Pope John Paul II elevated Rev. Marian Oleś to the rank of the Titular Archbishop of Ratiaria, which involved appointing him as Apostolic Pronuncio in Iraq and Kuwait, where he worked in 1987-1991. He was ordained as Bishop on 6 January 1988 by the Holy Father John Paul II in the Basilica of St. Peter at the Vatican. His motto was, "Fides et verax" (Faithful and true). When he was at the diplomatic post he showed extraordinary courage, valour and love of the Church. During so-called the first Iraq war ${ }^{8}$, he was the only one of all ambassadors who remained at the post, serving the Holy Father and the Holy See?

In April 1994, Archbishop Oleś was appointed as Apostolic Nuncio in the countries of Central Asia: Kazakhstan, Uzbekistan, Kyrgyzstan, Tajikistan and

ty in the world. Webpage: www.vatican.va/roman_curia/pontifical_academies/acdeccles/index.htm, lecture of 2 February 2016.

${ }^{7}$ The Congregation for Bishops - dicastery of the Roman Curia dealing with the legal condition of the local Churches of the Latin rite, and nominations and provisions of the bishops who are part of these Churches. The Cardinal Prefect heads the Congregation, and he is assisted by the secretary and undersecretary. The Congregation's powers include: The creation of new local Churches, provinces and regions of the church, their division, merger, and introduction of changes in the created ones; dealing with the matters related to the appointments of bishops and concern for the provisions of the local Churches; supervision over the pastoral activities of bishops; arranging the general apostolic visitations; preparation of bishops' visitations ad limina Apostolorum; dealing with the matters relating to convening local synods. With regard to the appointment of bishops and staffing bishopric sees, the Congregation conducts the procedure as to the suitability of the candidate in accordance with the canonical procedure and presents its opinion to the pope, who takes the final decision J. Krukowski, Kongregacja do spraw Biskupów, [in]: Catholic Encyclopaedia, volume 9 Lublin 2002, columns 609-610.

${ }^{8}$ The first Gulf War - was an armed conflict initiated on 2 August 1990 with an Iraqi attack on Kuwait, ended with the liberation of Kuwait by the international coalition in the spring of 1991 as part of a military operation "Desert Storm". The main reason for the aggression of Iraq was the issue of access to Kuwaiti oil fields, one of the largest in the world, whose extraction limits, set by OPEC, Kuwait was claimed to have violated. On 6 August this year, the UN Security Council imposed sanctions on Iraq. "Desert Storm" was carried out with the UN mandate. It was initiated on 17 January 1991, ended 28 February 1991with the liberation of Kuwait, into which, however, democratic reforms have not been introduced. Under the truce, Iraq relinquished the following areas to Kuwait: 120 square kilometres of the area with the oil field and part of the port of Umm Qasr. This boundary change was approved in 1992 by the United Nations. Iraq was obliged to pay huge compensation for damage in Kuwait and it was forced to destroy weapons of mass destruction. W. Hajnus, Mój Irak, Warszawa 2009, pp. 179-184.

${ }^{9}$ Then his attitude was similar to the attitude of the Nuncio to Poland, Archbishop Achiles Ratti. While Bolshevik's storm was coming to Warsaw in 1920, Nuncio Ratti did not leave the Nunciature in Warsaw in August that year; he stayed at his diplomatic post. B. Kumor, Historia Kościoła, part 8 Czasy wspótczesne, Lublin 1996, p. 21. 
Turkmenistan in the years 1994-2001, where he organized new diplomatic posts, formed pastoral centres, sought priests who could work there and took great care of them ${ }^{10}$. The scope of his diplomatic and pastoral activities was wide. He held interfaith dialogue, preached homilies and catechesis in various languages (he was fluent in seven languages) in different institutions and circles ${ }^{11}$. As a well-known and respected person among scholars, he earned the title of "Man of the Year", and at the University of Kazakhstan he was awarded the title "Honorary Professor".

His other posts were, in 2001-2002, Slovenia and Macedonia, where he quickly became the dean of the diplomatic corps ${ }^{12}$. Although for health reasons he retired on 1 May 2002, he remained very active. He travelled, gave lectures in New York, London, Chicago, wrote about the Church ${ }^{13}$. After the election of Cardinal Joseph Ratzinger to the papacy, he conceded that he had prayed and asked the Holy Spirit for help in his election.

Living and working away from his homeland, he treated it with extraordinary love. He frequently thought about his hometown Miastkowo. And when he was

${ }^{10}$ Since incorporating Kazakhstan into Russia in the 18th century, among others, the town of Petropavlovsk was the place of deportations of the Poles by tsarist authorities: confederates of Bar, insurgents of the January Uprising. The first Catholic church in that town was built by the Polish Siberians in 1901. At that time the local Catholics accounted for about 3.000 of the faithful in the deanery Omsk, in the Archdiocese of Mogilev. The erection of the Church dedicated to the Sacred Heart began in 1910. The construction of the church was interrupted by the October Revolution and the bloody persecution of the Church. In 1920 the Bolsheviks changed the church into a warehouse, and the Catholic Church in Petropavlovsk officially ceased to exist. Faith, however, did not cease. Over more than 70 years, the faithful, mostly the Poles and Germans, secretly gathered to pray in private homes, preserving the native tradition. At nights, the Catholics organized the Way of the Cross, and even the processions of Corpus Christi, secretly baptized their new-born children and prayed the rosary. On their own initiative, they looked for a priest so that he could preach, confess, celebrate the Eucharist and baptise. Among the priests who served the Catholics in Petropavlovsk were.: Rev. Władysław Bukowiński (1904-1974) from the Archdiocese of Cracow and Father Serafin Alojzy Kaszuba (1910-1977), a Capuchin - now they are both candidates for sainthood. It was not until 1991 that the Catholics of Northern Kazakhstan could freely organize their religious life. On 20 April 1993, Bishop Jan Pawel Lenga erected a parish church dedicated to the Holy Trinity in Petropavlovsk, and entrusted the pastoral care to the Redemptorists. The following year, the parish received a plot to build a church. The church was consecrated on 16 July 2000 by the Apostolic Nuncio in Kazakhstan - Archbishop Marian Oleś. the Parish of the Holy Trinity in Petropavlovsk, www.redemptor.pl, lecture of 14 October 2015.

${ }^{11}$ Archbishop Oleś also read Arabic.

${ }^{12}$ The diplomatic corps - diplomatic representatives accredited in the country. The corps does not have specific competence. It attends collectively at some ceremonies or intervene in case of violation of the privileges and immunities of any of its members. The corps is led by the dean.

${ }^{13}$ His article: "To who should the keys be entrusted?" is worth noting; it was published in "Dziennik Związkowy" in the USA under the pseudonym of Andrzej Tyszka. In this article, shortly before the death of Pope John Paul II, he wrote: "Every pontificate leaves a mark in the life of the Church. Despite all the differences, one cannot forget the continuation and compliance with the principles of all pontificates. This time they will probably entrust the keys to a man in his seventies. They will put a heavy cross on his shoulders and show him a bumpy road to Golgotha, where all his predecessors walked alone“. 
retired, he willingly visited his homeland and friends. During one of such visits, on 24 May 2005 he died suddenly in Warsaw, on the liturgical feast of Mary Help of Christians. On 30 May, on the liturgical feast of Saint Jan Sarkander, he was buried in the most famous cemetery in Poland - at the Powąki, in the tomb of the archbishops of Warsaw, thanks to the kindness of Cardinal Józef Glemp, the Polish Primate ${ }^{14}$. On his last earthly journey he was accompanied by Brothers in the Episcopate: the Polish Primate Cardinal Józef Glemp, Archbishop Józef Michalik - the President of the Polish Bishops' Conference, Archbishop Leszek Głódź - the Bishop of Warsaw-Praga, Archbishop Tomasz Peta of Kazakhstan, Archbishop Juliusz Paetz, the Bishop of Łomża Stanisław Stefanek, the Bishop of Łowicz Andrzej Franciszek Dziuba, Bishop Piotr Libera - the Secretary of the Polish Bishops' Conference, the representatives of the Order of Malta ${ }^{15}$ in the person of the main supervisor of the Chaplains Corps of the Order of Malta Poland - prior Regis N. Barwig from the United States, and many priests and the faithful. The funeral Mass was presided by the Apostolic Nuncio to Poland, Archbishop Józef Kowalczyk. Archbishop Leszek Głódź in his funeral homily emphasized the deceased's great love for the Church, the Holy See, homeland and family ${ }^{16}$.

In the memory of posterity, Archbishop Oleś was a man of deep faith; he lived with faith and passed it to others. He infected those who were around him with his youth spirit. He loved young people, enjoyed each meeting with the young, especially when visiting Polish parishes in England. He funded scholarships for poor young people. The thing that was especially important in his life was his love for the Church, whose expression was love for the Holy Father and the Holy See, which he served as a diplomat for 34 years. By decision of the Polish President Lech Wałęsa, on 7 September 1994, he was awarded the Officer's Cross of the Order of the Rebirth of Poland.

Keywords: Marian Oleś, Łomża, Archangielsk, England, The Pontifical Ecclesiastical Academy, Vatican Diplomacy, South America, Middle East, Asia Europe, Warsaw

${ }^{14}$ Archbishop Marian Oleś was buried next to Archbishop Bronisław Dąbrowski (1903-1992), a long-standing Secretary General of the Polish Bishop's Conference (1969-1993) and Senior Bishop of the Archdiocese of Warsaw Władysław Miziołek (1914-2000).

${ }^{15}$ Archbishop Marian Oleś was a member of the Order of Malta (the Hospitaller Order of St. John of Jerusalem, in 1310 it became the Order of the Knights of Rhodes, since 1530 the Order of Malta, the Sovereign Order of the Knights of St. John of Jerusalem) - the first Christian order of this type, founded in the $12^{\text {th }}$ century in Jerusalem. Currently, the aim of the order is charity, including helping patients with leprosy in Africa, victims of wars, accidents and disasters. These tasks are done by hospitals, clinics, ambulances and emergency assistance groups. As a chaplain of the Conventual Grand Cross of the Order, the Archbishop assisted the poor and the suffering. In 1991, the Order established diplomatic relations with Poland. M. Daniluk, Joannici, [in]: Catholic Encyclopaedia, volume 8, Lublin 2000, pp. 38-46.

${ }^{16}$ W. Wyszowadzki, W trosce o Kościót i Polonię. Wybór publicystyki z lat 1982-2014, ed. M. Nabożny, Lublin 2015, pp. 151-152. 